\title{
Using the Change Point Model (CPM) Framework to Identify Windows for Water Resource Management Action in the Lower Colorado River Basin of Texas, USA
}

\author{
Brendan L. Lavy ${ }^{1, *(D)}$, Russell C. Weaver ${ }^{2}$ and Ronald R. Hagelman III ${ }^{3}$ \\ 1 Department of Environmental Sciences, Texas Christian University, Fort Worth, TX 76109, USA \\ 2 ILR Buffalo Co-Lab, Cornell University, Buffalo, NY 14203, USA; rcweaver@cornell.edu \\ 3 Department of Geography, Texas State University, San Marcos, TX 78666, USA; rhagelman@txstate.edu \\ * Correspondence: b.lavy@tcu.edu; Tel.: +1-817-257-7273
}

Citation: Lavy, B.L.; Weaver, R.C.; Hagelman, R.R., III. Using the Change Point Model (CPM)

Framework to Identify Windows for Water Resource Management Action in the Lower Colorado River Basin of Texas, USA. Water 2022, 14, 18. https://doi.org/10.3390/ w14010018

Academic Editors: Briana Wyatt, Gehendra Kharel and Bharat Sharma Acharya

Received: 9 November 2021 Accepted: 16 December 2021 Published: 22 December 2021

Publisher's Note: MDPI stays neutral with regard to jurisdictional claims in published maps and institutional affiliations.

Copyright: (C) 2021 by the authors. Licensee MDPI, Basel, Switzerland. This article is an open access article distributed under the terms and conditions of the Creative Commons Attribution (CC BY) license (https:// creativecommons.org/licenses/by/ $4.0 /)$.

\begin{abstract}
In water-stressed river basins with growing urban populations, conflicts over water resources have emerged between urban and agricultural interests, as managerial interventions occur with little warning and tend to favor urban over agricultural water uses. This research documents changes in water use along an urban-to-agricultural gradient to examine whether it is possible to leverage temporal fluctuations in key quantitative data indicators to detect periods in which we could expect substantive managerial interventions in water resource management. We employ the change point model (CPM) framework to locate shifts in water use, climate-related indicators, lake and river characteristics, and agricultural trends across urban and agricultural counties in the lower Colorado River basin of Texas. Three distinctive groupings of change points appear. Increasing water use by urban counties and a shift in local climate conditions characterize the first period. Declines in agricultural counties' water use and crop production define the second. Drops in lake levels, lower river discharge, and an extended drought mark the third. We interpret the results relative to documented managerial intervention events and show that managerial interventions occur during and after significant change points. We conclude that the CPM framework may be used to monitor the optimal timing of managerial interventions and their effects to avoid negative outcomes.
\end{abstract}

Keywords: water use; water management; water conflict; urban; agriculture; change point model (CPM); time series analysis

\section{Introduction}

Population growth, economic development, and a changing climate are increasing competition for water resources across the world [1-3]. Competing interests vying for dwindling water resources are testing the institutions, infrastructure, and policies that govern water allocation. In many developed nations, traditional water resources allocation systems-a number of which were created over a century ago-are ill-equipped to respond to additional water demands and increases in water-related hazards, such as drought and floods [2,3]. Many water allocation systems are gradually transferring water from uses of low economic return to those that produce a high economic return. Much of these transfers have moved water from agricultural uses to industrial and urban uses [4,5]. Reallocation of agricultural water, however, is frequently contentious [6-8], and conflicts over access to water resources have emerged, as allocation systems struggle to balance urban and agricultural needs with environmental and economic needs. These trends are expected to extend into the near future, especially in water-stressed regions [1]. Because of this, understanding how physical and social feedback in water-stressed basins triggers managerial responses, as well as the outcomes of these responses, is an important component in helping institutional and management systems transition to more sustainable water governance [9].

Opening sustainable pathways to enhance water governance is particularly important in water-stressed regions of the United States. Water scarcity is high across large swaths 
of the central, southern, and western United States [10-12]. In these areas, approximately 130 million people experience severe water scarcity during a portion of the year [12], as demands on many U.S. river basins approach the amount of freshwater available. In particular, consumptive water use in the Rio Grande and lower Colorado river basins is one-half of the total renewable supply, and in the California, Great Basin, Missouri Basin, and Texas Gulf regions, consumptive water use is between 20 and 40 percent of the renewable supply [13]. These U.S. regions historically supported irrigated agricultural crop production - and many still do. Yet, during times of scarcity, water allocation systems in these regions have struggled to meet the demands of all users, and conflicts have emerged, as growing urban areas compete with agricultural interests. Many of the conflicts have surfaced because of rigid allocation systems that continue to operate under rules and regulations created under a pro-water development ideology that began over a century ago.

Research has shown that an urban bias exists in issues of water development and management, where municipal water interests prevail over other water interests $[7,14-19]$. Provisioning of water for growing urban areas often requires the expansion of the urban hydraulic reach via securing or appropriating water from sources in rural areas. Water management authorities tend to transfer water resources that were historically assigned to agricultural uses to nearby cities $[4,20,21]$. Moreover, during times of acute water shortage, allocation systems may curtail or cut off water previously assigned to agricultural uses in favor of municipal and industrial uses [4].

Empirical evidence regarding the impacts of water shifts from agricultural uses to urban uses is mixed and highly complex. The reallocation of agricultural water to other uses directly dictates how much water agricultural communities receive and when, limiting agricultural production and producing multiple effects that ripple across the agricultural community with varying social and economic outcomes [6]. For example, water transfers from agricultural areas affect not only agricultural interests but also the surrounding community and its collective social identity and economic development [22,23]. Yet, research has also shown that regional economic growth may be enhanced through water reallocation via water markets [24,25].

Furthermore, societal responses to water scarcity are dependent on both the environmental and social landscapes present within a river basin, as well as the historical transformation of the basin [26]. For example, weather-related events, such as drought, coupled with changes in water demand and regional economic development goals affect water supplies and influence water laws and policies. In turn, water laws and policies established to allocate available water supplies across water interests guide the allocation decision-making process. Decisions are often based on water availability data established during earlier drought conditions. In other words, water allocation decisions are reactions to previous environmental conditions. The decision-making process, however, is more complex and dynamic. Decisions are made in response to feedback not only from the physical environment (i.e., environmental perception of decision makers) but also from the social landscape (i.e., socio-economic and technical data and input from competing interest groups) [27]. The purpose of this research is to examine whether it is possible to leverage temporal fluctuations in key quantitative data indicators (i.e., feedback from environmental and social systems) to detect periods in which we could expect substantive managerial interventions or, on the other hand, to reveal periods in which we could expect to observe responses to substantive managerial interventions. We ask: (1) in what years do significant changes occur in water use and access among urban and agricultural interests, and (2) how do these changes align with documented managerial water resource decisions? We use the change point model (CPM) framework to locate significant years of change across a host of socio-ecological time series data sets. Over the past five years, researchers have applied the CPM framework to monitor changes in environmental, geological, and public health data [28-30]. 


\section{Materials and Methods}

\subsection{Site and Situation}

The study area for this research is the lower portion of the Colorado River basin in Texas (Figure 1). The lower Colorado River flows through the Texas Hill Country prior to reaching the Balcones Escarpment. In this area of uplift, canyons carved by the river provide the ideal geography for water development projects to protect urban areas from perennial floods and to produce electricity for the surrounding area [31]. Just downstream from the Balcones Escarpment region, the Colorado River enters Austin, the capital city of Texas, and then winds its way southwest through the Blackland Prairies, where it widens and encounters the Gulf Coastal Plain before discharging into Matagorda Bay and the Gulf of Mexico. The lower Colorado River basin provides an ideal place in which to explore changes in the relationship between urban and agricultural water interests for several reasons.

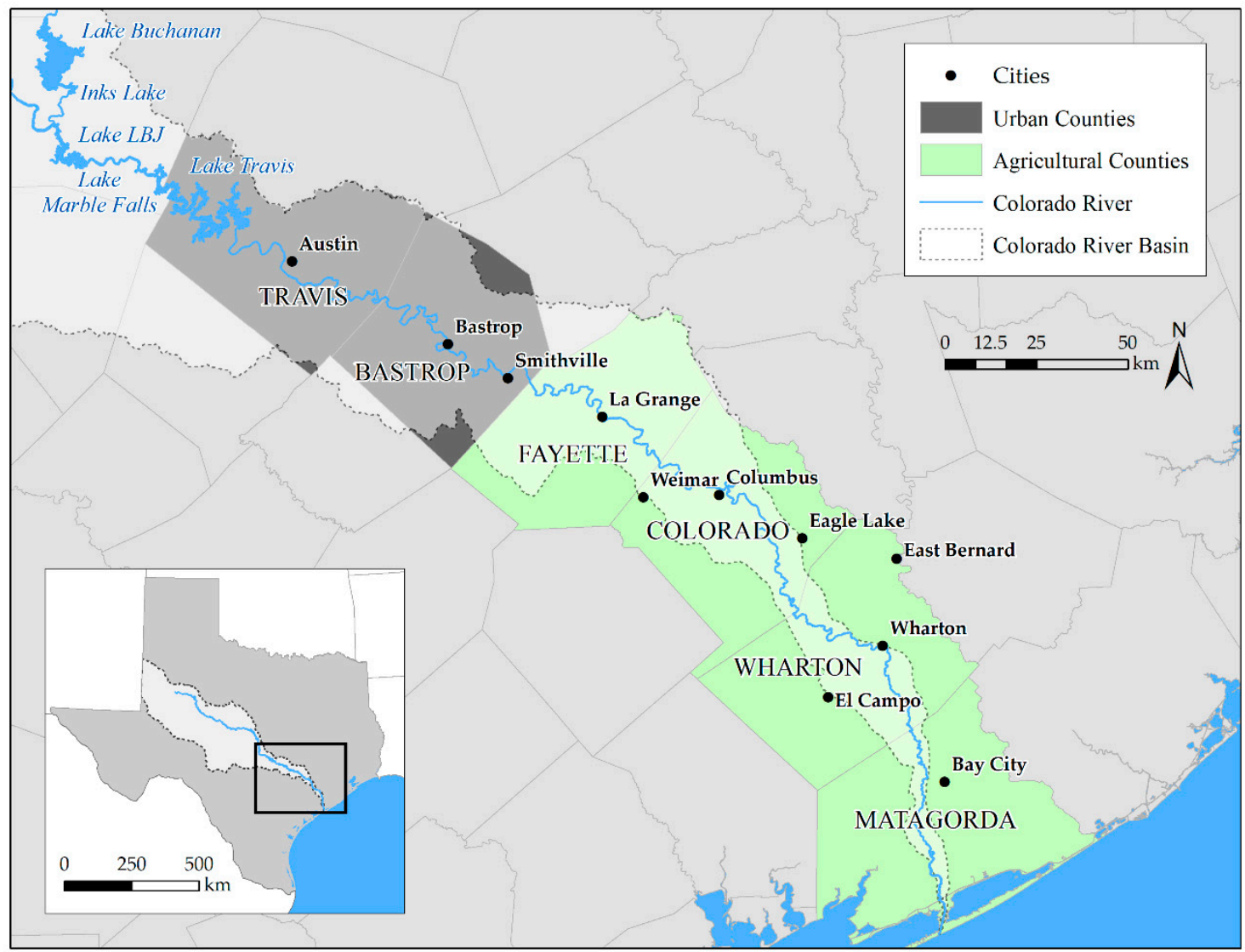

Figure 1. Study area of the lower Colorado River basin in Texas.

First, precipitation along the course of the Colorado River is highly variable. Precipitation totals near the river's headwaters range around 10 to 15 inches per year (254 to $381 \mathrm{~mm})$, whereas totals near the Gulf may be as much as 40 inches per year $(1016 \mathrm{~mm})$ [32]. The area is prone to cyclical droughts, with approximate decadal intervals related to El Nino-Southern Oscillation (ENSO) events [33]. The climatological drought of record occurred between 1950 and 1954. The area also encountered an extended drought that peaked in 2011 [34]. During periods of drought, area lake and reservoir levels fall to historic lows, which prohibits water authorities from meeting all water demands.

Second, the Colorado River does not pass through a major metropolitan region until it reaches Austin and its wider conurbation (Figure 1), and after leaving Austin, the Colorado River does not encounter any other major metropolitan areas before draining into Matagorda Bay [35]. The river's upper reaches include the urban-centric counties of Travis 
and Bastrop. Populations in these counties, among others in central Texas, have grown rapidly since the 1990s. Austin's population growth ranks among the highest in the United States. Its population doubled from 1990 to 2010 [36].

Third, as the Colorado River approaches the Gulf of Mexico, its waters have supported a large agricultural community. Texas consistently ranks fourth or fifth in U.S. rice production per year [37]. Colorado, Wharton, and Matagorda counties produce the majority of Texas's rice crop. Rice cultivation in the region began in the late 1800 s and continues to play a prominent role in the culture, society, and economy of Texas's south coastal region. Yet, the number of rice farms in Texas is declining due to water availability, climatic factors, and higher production costs. From 1992 to 2007, the Texas Gulf Coast rice production region lost 46 percent of its rice area [37]. Rice operations depend on surface water from the Colorado River and water stored in the Highland Lakes.

Fourth, the basin has an extensive history of regional water resource management, along with numerous river modifications and infrastructure developments and documented periods of cooperation and conflict among water interests [31,38,39]. The Lower Colorado River Authority (LCRA), a quasi-governmental agency created by the Texas Legislature, has developed and managed water supplies in the basin via projects related to flood control, hydroelectric power, and irrigation operations since 1934. With financial support of the federal government, policymakers modeled the LCRA after the Tennessee Valley Authority (TVA). LCRA was instrumental in the development of water resources in the basin. It oversaw the construction of multiple dams along the Colorado River from the 1930s to 1960s [31]. Today, the LCRA serves as the primary authority regarding the allocation of surface water resources collected and stored in the Highland Lakes. It owns the rights to 2.1 million acre-feet of water per year. It also owns three irrigation districts in southwest Texas and operates 11 major pumping plants and a $1770 \mathrm{~km}$ (1100-mile) network of irrigation canals [40]. The LCRA distinguishes between two water types: (1) firm and (2) interruptible water. Cities, industry, and power plants possess firm water contracts, which guarantee water supply even during periods of drought. Agricultural interests enter into interruptible water contracts on a yearly basis. The LCRA may be curtailed or cut off interruptible water supply completely during times of drought.

Finally, there is also a growing interest in the ecological functions of the various Gulf Coastal estuaries in Texas, including Matagorda Bay, among environmentalists and recreationalists. This has generated an awareness of the importance of freshwater inflows to sustain the health and wellbeing of bay ecosystems. Recent legislation has followed and stipulated environmental flow standards be developed for each Texas river basin $[35,41]$. This adds another water use dimension to water resource management in a fully allocated basin subject to acute, chronic periods of drought.

\subsection{Data}

We divided the six counties in the study area into urban counties and agricultural counties using water use estimates gathered from the Texas Water Development Board (TWDB). We classified counties with most of their total water use for agricultural purposes as agricultural counties and counties with most of their total water use for municipal and industrial purposes as urban counties.

Next, we operationalized a set of conceptual variables related to the primary factors driving competition to access water resources [1-3]. We included data, acquired from federal and state institutions, related to local climate trends, basin-wide water usage characteristics, lake level information, agricultural production measurements, and population and income characteristics (Table 1). We aggregated the data sets by year and county. We discuss each data set below. 
Table 1. List of conceptual and operational variables. Operational variables were converted to continuous annual time series described in Section 2.2.

\begin{tabular}{|c|c|c|}
\hline Conceptual Variables & Operational Variables & Units \\
\hline \multirow[b]{2}{*}{ Climate-related indicators } & Annual mean maximum temperature & degrees Fahrenheit \\
\hline & Summer mean maximum temperature & degrees Fahrenheit \\
\hline \multirow{5}{*}{$\begin{array}{l}\text { Lake and river } \\
\text { characteristics }\end{array}$} & Lake Buchanan (annual mean sea level) & feet (ft; $0.30 \mathrm{~m})$ \\
\hline & Lake Buchanan (summer mean sea level) & feet \\
\hline & Lake Travis (annual mean sea level) & feet \\
\hline & Lake Travis (summer mean sea level) & feet \\
\hline & Mean summer river discharge & cubic feet per second (CFS; $\left.0.028 \mathrm{~m}^{3} \mathrm{~s}^{-1}\right)$ ) \\
\hline Water usage & Urban counties water use & $\begin{array}{l}\text { thousands of acre-feet per year (AFY; } \\
\left.\qquad 1.23 \times 10^{6} \mathrm{~m}^{3} \text { year }^{-1}\right)\end{array}$ \\
\hline \multirow{9}{*}{ information } & Surface water use & thousands AFY \\
\hline & Groundwater use & thousands AFY \\
\hline & Water use per capita & thousands AFY \\
\hline & Water share & proportion \\
\hline & Agricultural counties water use & thousands of AFY \\
\hline & Surface water use & thousands of AFY \\
\hline & Groundwater use & thousands of AFY \\
\hline & Water use per capita & thousands of AFY \\
\hline & Water share & proportion \\
\hline \multirow{4}{*}{ Agricultural characteristics } & Total field crops harvested & thousands of acres (ac; 0.405 ha) \\
\hline & Rice harvested & thousands of acres \\
\hline & Rice produced & thousands of hundredweight (cwt; $4.54 \times 10^{4} \mathrm{~kg}$ ) \\
\hline & Rice share of harvest & proportion \\
\hline
\end{tabular}

\subsubsection{Climate-Related Indicators}

The central Texas region experiences recurring floods and acute, chronic droughts. The region's water supply (collected in the Highland Lakes) varies, depending primarily on precipitation in the upper portions of the Colorado River watershed, which can range from less than 15 to 30 inches per year ( 381 to $762 \mathrm{~mm}$ ). While the region's water demand is expected to increase, its water supply is expected to decline under current climate change scenarios [42]. Empirical evidence suggests that changes in climate influence water use [43] and decisions related to water allocation and management [44-46]. In other words, the amount of water available (i.e., water supply) and water demand guide water usage and influence allocation decisions. Therefore, precipitation and temperature play important roles in determining water supply, water demand, and water usage. In general, precipitation determines water supply, whereas temperature dictates water demand. Both relate to water usage. Under wet conditions and normal temperatures, water use generally decreases, and under drought conditions and warmer temperatures, water use typically increases [47]. Given the relationship between precipitation, temperature, water supply, water demand, and water usage, we selected climate-related variables to ascertain the extent to which they have influenced water use and access in the basin. Because rice is the dominant crop in the agricultural counties in the study area, we collected climate-related data to coincide with the rice-growing season. We gathered climate-related data from a variety of sources, and from these data sets, we defined wet and dry periods and captured summer temperature trends.

We acquired historical precipitation and temperature data reported from Camp Mabry at station site USW00013958 in Austin, Texas, from the National Oceanic and Atmospheric Administration's (NOAA) National Climatic Data Center (NCDC). We chose Camp Mabry because of its relatively long data collection and data coverage over its period of record from 1938 to 2016. Using the temperature data set, we calculated mean maximum summer temperatures (May, June, July, August) and mean summer temperature trends. Both calculations provided a sense of changing climatic conditions experienced in the upper portions of the lower Colorado River watershed. 
We used monthly precipitation totals to calculate a Standard Precipitation Index (SPI) for the area to ascertain abnormally wet and dry periods within the region [48-50]. Developed in 1993, SPI is a tool designed to define and monitor drought over several timescales using monthly precipitation data [48]. We used a 12-month timescale because the longer period reflects stream flows, reservoir levels, and groundwater levels and because the 12-month SPI is similar to the Palmer Severity Drought Index [51]. The index is calculated by fitting long-term, monthly precipitation data to a cumulative probability function with a range of 3 to -3 [52], where a drought event begins when the SPI is continuously negative and reaches an intensity of -1.0 or less and ends when the SPI becomes positive [51].

\subsubsection{Lake and River Characteristics}

Lakes Buchanan and Travis-the two largest lakes in the system-serve as water storage for the basin. Today, annual water releases from Lake Buchanan feed the irrigation districts in the lower reaches of the river, and water stored in Lake Travis supplies water to the nearby residents of Austin and other central Texas urban populations. Lake levels are an important indicator of the basin's available water supply. As such, we gathered historical lake level information from the LCRA and calculated mean summer averages for both lakes Buchanan and Travis.

The timing and availability of water are critical to rice farmers in the valley. Rice farmers plant crops in mid to late March, and by late April, they flood-irrigate their rice fields. Flood irrigation is needed until a week to ten days before harvest, which usually begins in late July. After the initial harvest, rice fields may be flood-irrigated again to produce a second (or ratoon) crop. Thus, the rice-growing season dictates the timing of water releases. Water must be available to rice farmers by late April or early May and remain available until late August. In dry years, when river flows are low, rice farmers depend on water releases from Lakes Buchanan and Travis in the Highland Lakes system.

We collected mean daily river discharge from the U.S. Geological Survey (USGS) for the period of record (1916 to 2016) at station site 08161000, corresponding to the Colorado River at Columbus, Texas. We selected this location for two reasons. First, it has a lengthy period of record and sustained data coverage. Second, it is in Colorado County upriver from most rice farms, and therefore, river flow at this location is less likely to be the result of return flows from ongoing flood irrigation. We analyzed the river flow data using The Nature Conservancy's Indicators of Hydrologic Alteration (IHA), Version 7.1 [53]. Specifically, we used IHA's calculations of Environmental Flow Components (EFCs) as a proxy measure for hydrological drought in the region. IHA calculates five EFCs: extreme low flows, low flows, high-flow pulses, small floods, and large floods [54]. Research ecologists use the EFCs to monitor flow regimes in rivers in an effort to assess river functions for the maintenance of dependent ecosystems [55]. For the purposes of this research, we documented periods of extreme low flow because of its potential impact on rice-farming operations. Extreme low flows correspond to the 10th percentile of all low flows [56]. Thus, periods of extreme low flow correspond to hydrological drought and limit water available for flood irrigation. We also documented large floods to provide information on their frequency compared to normal and extreme low flow periods. Large floods correspond to flows that were equal to or greater than the 10-year flood [56].

\subsubsection{Water Usage Information}

We obtained water use information from the Texas Water Development Board (TWDB) annual estimates of water use. The TWDB conducts an annual survey of groundwater and surface water use by municipal and industrial entities within Texas. It also collects groundwater and surface water use estimates for irrigation, livestock, and mining. The TWDB issues municipal and industrial surveys annually. The TWBD surveys approximately 4500 public water systems and 2500 industrial water users. If selected, the Texas Water Code requires water entities to complete and return the survey in 60 days. The TWDB 
uses the information gathered through their annual water survey to estimate the amount of water used for municipal, manufacturing, and steam-electric power. It also estimates water used for mining and in secondary processes for oil and gas recovery. The TWDB compiles agricultural water uses from a variety of sources. The TWDB uses annual livestock population estimates produced by the Texas Agricultural Statistics Service (TASS) and estimated water use per animal unit based on research conducted by the Texas Agricultural Experiment Station (TAES) to estimate water used for livestock estimates. The TWDB has used two sources to estimate water used for agricultural irrigation. The TWDB calculated estimates before 2001 using annual crop acreage from the Natural Resources Conservation Service (NRCS) and estimates for 2001 and later using annual crop acreage from the Farm Service Administration (FSA). We collected water use data for each year the estimates were available, beginning in 1984 and ending in 2014.

\subsubsection{Agricultural Characteristics}

Agriculture production, particularly rice farming, plays an important role in the economies of the lower basin counties. Water captured in the Highland Lakes system feeds the irrigation districts, and many rice farmers depend on surface water releases to flood-irrigate their first and second rice crops. Yet, continued urbanization has resulted in less water for agricultural communities [20,57]. Because of the relationship between water, agricultural production, and the lower counties' economies, as well as increasing urban pressure on agricultural water sources, we gathered data related to agricultural production in Fayette, Colorado, Wharton, and Matagorda counties. We collected data related to farming operations and harvested field crops. Since rice is the primary crop in the agricultural counties and is a water-intensive crop, we primarily focused on rice. We looked at rice acres harvested and the amount of rice produced. We also calculated the rice share of the acres harvested in the counties from 1970 to 2015. We gathered all agricultural information from agricultural censuses conducted by either the U.S. Census Bureau or the U.S. Department of Agriculture's (USDA) National Agricultural Statistical Service (NASS).

The U.S. Census Bureau collected agricultural data from 1840 to 1996. In 1997, the U.S. Congress passed the responsibility for conducting the agricultural census to the USDA's NASS. The NASS conducts the agricultural census every 5 years. It also conducts surveys each year on agricultural production, economics, demographics, and the environment to provide annual estimates of important agricultural markers. We gathered data from both surveys and censuses.

\subsection{Analysis}

From the data gathered, we developed annual time series data sets for each continuous variable from 1970 to 2015 . We analyzed the continuous time series variables using the change point model (CPM) framework to identify significant change points [58,59]. Researchers have used similar techniques to monitor environmental time series data [30,60-62]. Next, we used the resultant change points to identify empirical "windows of change" in which indicators suggested heightened competition for water resources between urban and agricultural counties in the study area. Finally, we situated documented managerial interventions (i.e., laws, policies, or restrictions) related to water resource management into the overall timeframe, comparing the timing of interventions to the empirically detected windows of change.

\section{Change Point Detection}

The CPM framework developed by Hawkins, et al. [63] and Hawkins and Zamba [64] identifies points at which the process that underlies a time series pattern for a given continuous random variable undergoes meaningful changes. These changes are detected as shifts in the location or scale parameters of the continuous variable's temporal distribution. The CPM framework was derived from control charts created to monitor industrial and operation processes for quality control via statistical process control (SPC). The goal of SPC is to detect when a process or system has gone out of statistical control $[58,64]$. The 
objectives of SPC "may include providing a signal that the process is out of control, an estimate of when it went out of control, and a diagnosis of the way in which it went out of control-for example, whether the mean shifted, the variance jumped, or either of the quantities started a slow drift" [64]. In industrial and operation settings, analysts use this information to diagnose the cause of the change in an effort to bring the process back under control.

Common methods for SPC have included the Shewart, the cumulative sum (cusum), and the exponentially weighted moving average (EWMA) control charts [58,64]. Shewart control charts detect shifts in mean and standard deviation. The cusum and EWMA control charts detect shifts in mean [64]. These methods require that the in-control distribution be known, including the mean and variance. The in-control distribution is determined using a fixed-size sample during what is called Phase I analysis. Once the distribution is known, the process may be monitored sequentially for changes during a subsequent Phase II analysis [65]. Yet, the in-control mean and variance of a system's process are difficult to pinpoint accurately. As such, the CPM framework bypasses the need for Phase I analysis and analyzes all process readings to detect the presence of a change point [63]. Their formulation detects a mean shift in a normally distributed random variable. The CPM framework has been extended to include analysis of nonparametric data sets as well (for example, see [58,65]).

The CPM may be conceived of as follows. Let us consider the continuous time series of annual urban water use $\left(X_{1}, X_{2}, \ldots X_{n}\right)$ and assume water use over time follows a single distribution $\left(F_{0}\right)$. The change point model looks for changes in the distribution of the time series or, in this example, changes in urban water use (AFY) that deviate from the initial distribution $\left(F_{0}\right)$. It does so by dividing the time series into two subseries $\left(x_{1}\right.$, $\left.x_{\times 2}, \ldots x_{\times \mathrm{k}}\right)$ and $\left(x_{\times \mathrm{k}+1}, x_{\times \mathrm{k}+2}, \ldots x_{\times \mathrm{n}}\right)$, and implementing a two-sample test to determine whether differences exist between the two subseries. If the differences occur in the statistical properties of the two subseries, then a change point has been located. Thus, the subseries before the change point has a distribution $F_{0}$, and the subseries after the change point has a distribution $F_{1}$, where $F_{0}$ does not equal $F_{1}$. From this, two hypotheses emerge. The null hypothesis for this example is defined as (following $[58,64]$ )

$$
H_{0}: X_{i} \sim F_{0}\left(x ; \theta_{0}\right), i=1, \ldots, n
$$

where urban water use $X$ at any given year $i$ in the time series follows a single distribution $F_{0}$. This distribution $F_{0}$ is a function of $X_{i}$ and a set of unknown parameters $\theta_{\mathrm{i}}$. The alternative hypothesis is defined as

$$
H_{1}: X_{i} \sim\left\{\begin{array}{cc}
F_{0}\left(x ; \theta_{0}\right) & i=1,2, \ldots, k \\
F_{1}\left(x ; \theta_{1}\right) & i=k+1, k+2, \ldots, n
\end{array}\right.
$$

where urban water use $X_{i}$ follows distribution $F_{0}$ with parameter $\theta_{0}$ before change point $k$. After change point $k$, urban water use $X_{i}$ follows distribution $F_{1}$ with parameter $\theta_{1}$.

This formulation has been extended by Ross [58] to include sequential monitoring (Phase II analysis) and detection of multiple change points via both parametric and nonparametric methods. We used the cpm package in $\mathrm{R}$ to look for change points in continuous time series variables $[58,59]$.

Because our time series data sets were not normally distributed, we tested the null hypothesis using the Mann-Whitney $U$ statistic. The cpm package calculates the MannWhitney $U$ statistic using the subseries before and after every time interval, evaluating whether statistically significant differences occur between each before and after subseries. If the test statistic is greater than what would be expected by chance, a change point is detected. If a change point occurs, the cpm package returns two results: (1) a detection time and (2) a change point. The detection time refers to "the observation at which a change point was detected" [58]. The change point refers to "the maximum likelihood estimate (MLE) of the change point $\tau$, defined as the value of $k$ for which $D_{k, n}$ [Mann-Whitney $U$ 
statistic] is maximum when $n=T$ and $T$ is the detection time" [58]. Thus, the MLE change point denotes the best estimate of the change point location. To prevent returning a false positive (i.e., detecting a false change point), we set a conservative 99.9 percent confidence level (or $A R L_{0}=1000$ ).

Based on the reactive nature of much public decision making, we expect to observe water resource management actions taking place after change points (i.e., after decision makers receive feedback from physical and social systems that action is needed) [27].

\section{Results}

Results of the CPM analysis of time series variables detected several annual change points. The first change point occurred in 1974 and the last in 2007. The CPM returned no change point for urban counties' per capita water use. For the remaining variables, the CPM analysis returned at least one change point. Multiple change points were detected in two variables: (1) rice acres harvested (1982 and 1999) and (2) rice share of the total field crops harvested (1974 and 1995).

For both climate-related variables, the results of the CPM analysis rejected the null hypothesis. The critical value of $U$ was exceeded and reached a maximum value in 1997, indicating a shift occurred in the time series data sets for the mean annual maximum and the mean maximum summer temperature (Figure 2A,B). Since 1997, temperatures in central Texas increased.
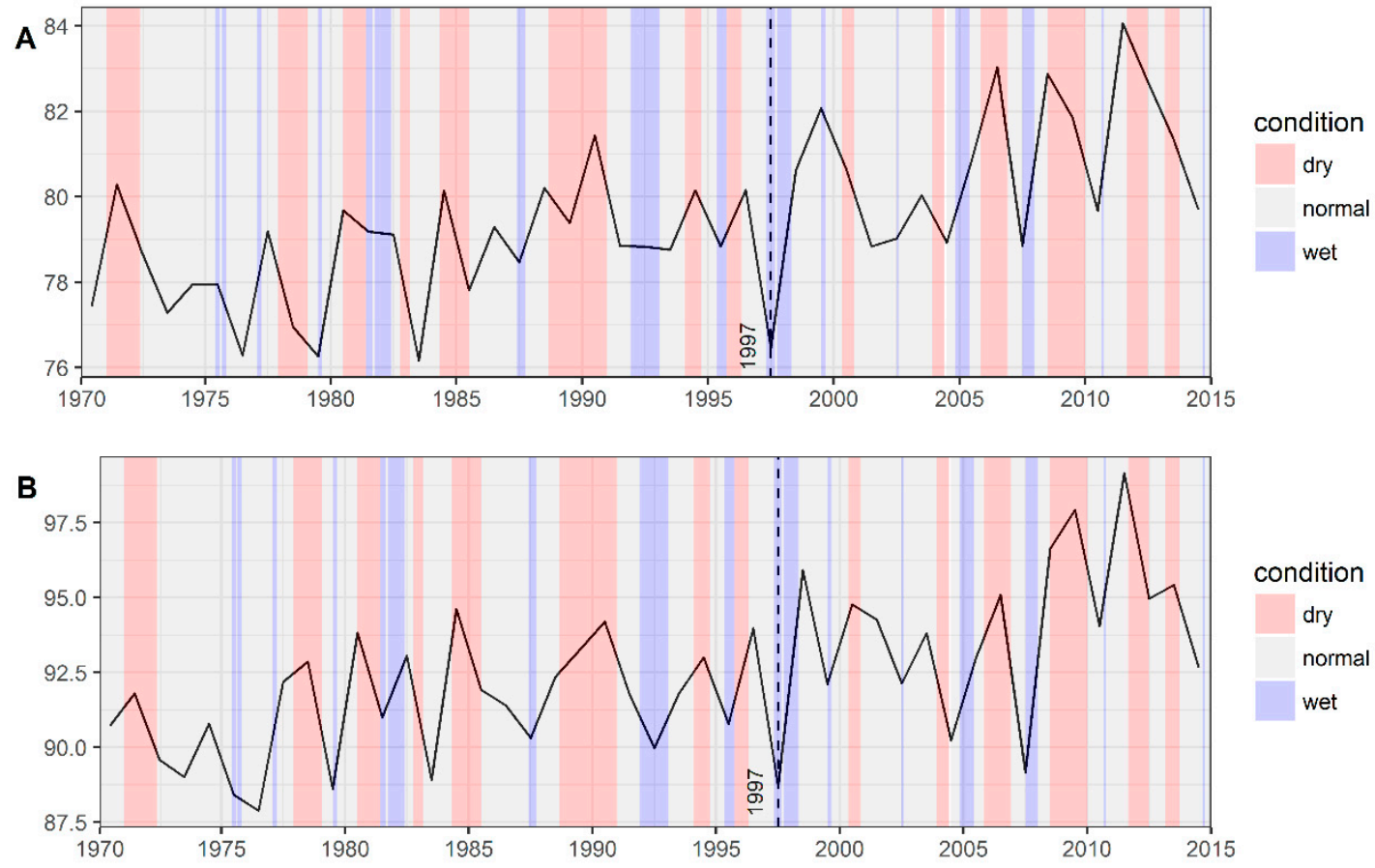

Figure 2. Change points for climate-related indicators overlaid against SPI calculations for periods of dry, normal, and wet conditions: (A) mean annual maximum temperature and (B) mean maximum summer temperature measured in degrees Fahrenheit.

The null hypothesis was rejected for all lake and river characteristics tested. The annual mean levels for lakes Buchanan and Travis exceeded critical values for $U$ in 2005 (Figure 3A,C). The summer mean level for Lake Buchanan signaled in the same year (Figure 3B). Yet, critical values of $U$ for Lake Travis's summer mean level (Figure 3D) and for the mean summer river discharge (Figure 4) near Columbus, Texas, were exceeded two years later in 2007. All significant shifts in the time series data sets detected by the CPM indicated decreases in the lake levels and river discharge. 

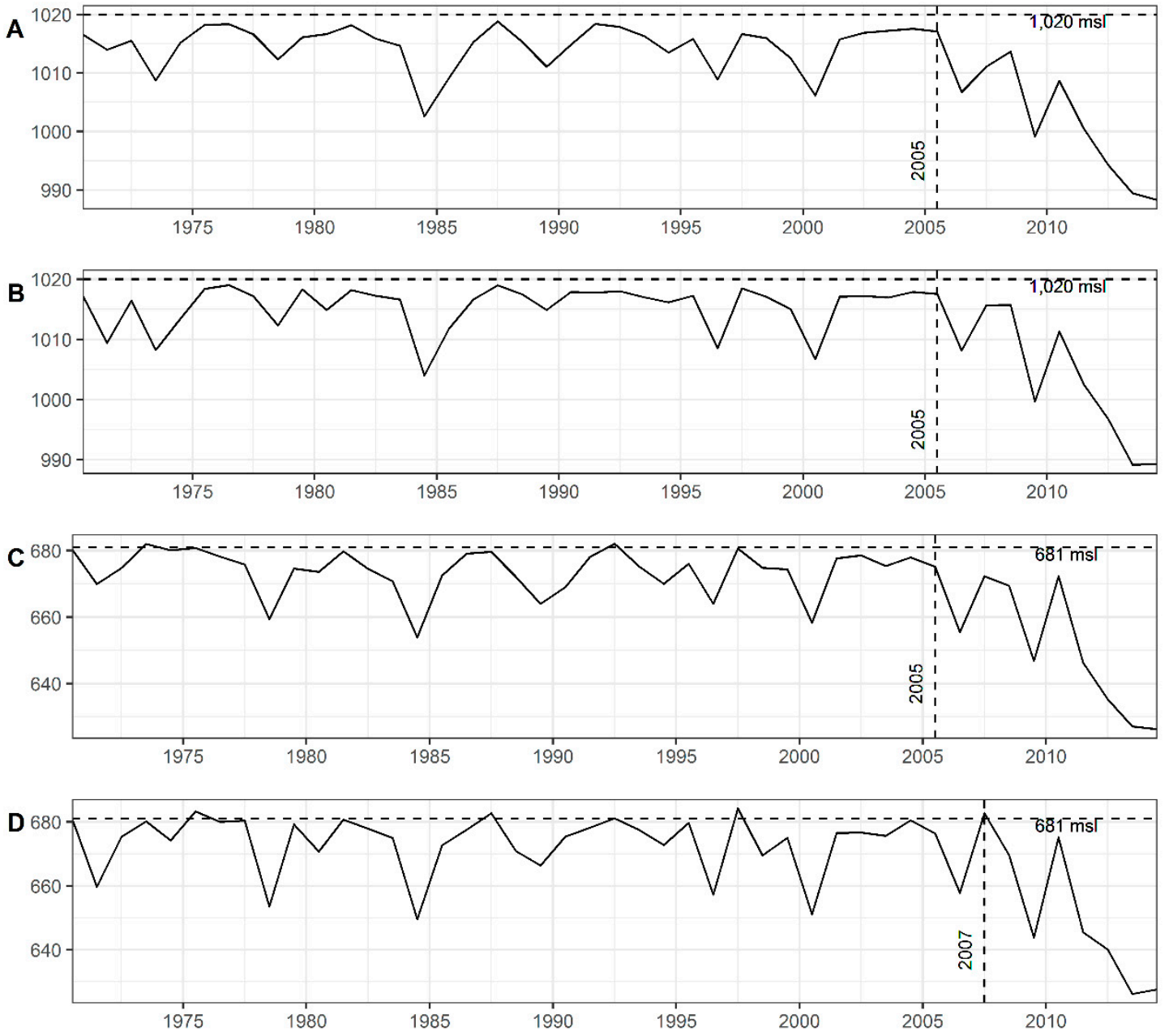

Figure 3. Change points for lake characteristics: Lake Buchanan (A) annual mean level and (B) annual summer level and Lake Travis (C) annual mean level and (D) annual summer level from 1970 to 2014. Each lake level measured in feet above mean sea level (msl). Horizontal dashed line represents the level (msl) when the lake is at capacity.

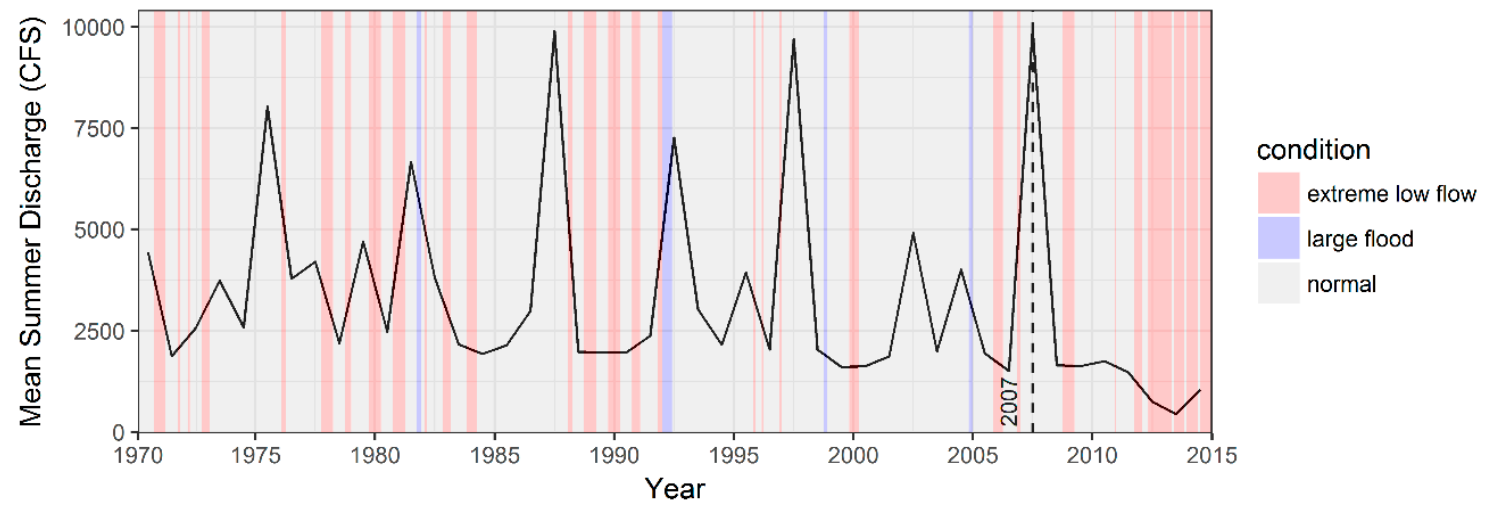

Figure 4. Change point for river characteristics: Mean annual summer discharge (CFS) on the Colorado River near Columbus, Texas, from 1970 to 2014, overlaid against IHA calculations for periods of extreme low flow, large floods, and normal conditions.

Critical values of $U$ were exceeded for several water usage variables, and the null hypothesis was rejected. Urban counties' water use (from groundwater and surface water sources) signaled in 1994, indicating an increase in water usage (Figure 5A). Surface water 
use by urban counties also returned a change point in 1994, corresponding to increasing usage (Figure 5B). Similarly, groundwater use in urban counties reached its maximum $U$ value in 1997 (Figure 5C). Per capita water usage in urban counties failed to reject the null hypothesis; however, per capita consumption generally declined during the study period (Figure 5D). Urban counties' share of water signaled in 1996, marking the point where urban counties began to increase their consumption of the basin's water resources and the decline of the agricultural counties' water consumption (Figure 5E). Agricultural counties' water consumption declined during the study period. Water use, groundwater use, and water use per capita reached maximum $U$ values a couple of years later in 1999 (Figure 6A,C,D, respectively), paralleling decreased water usage. Surface water use signaled two years later in 2001 (Figure 6B).
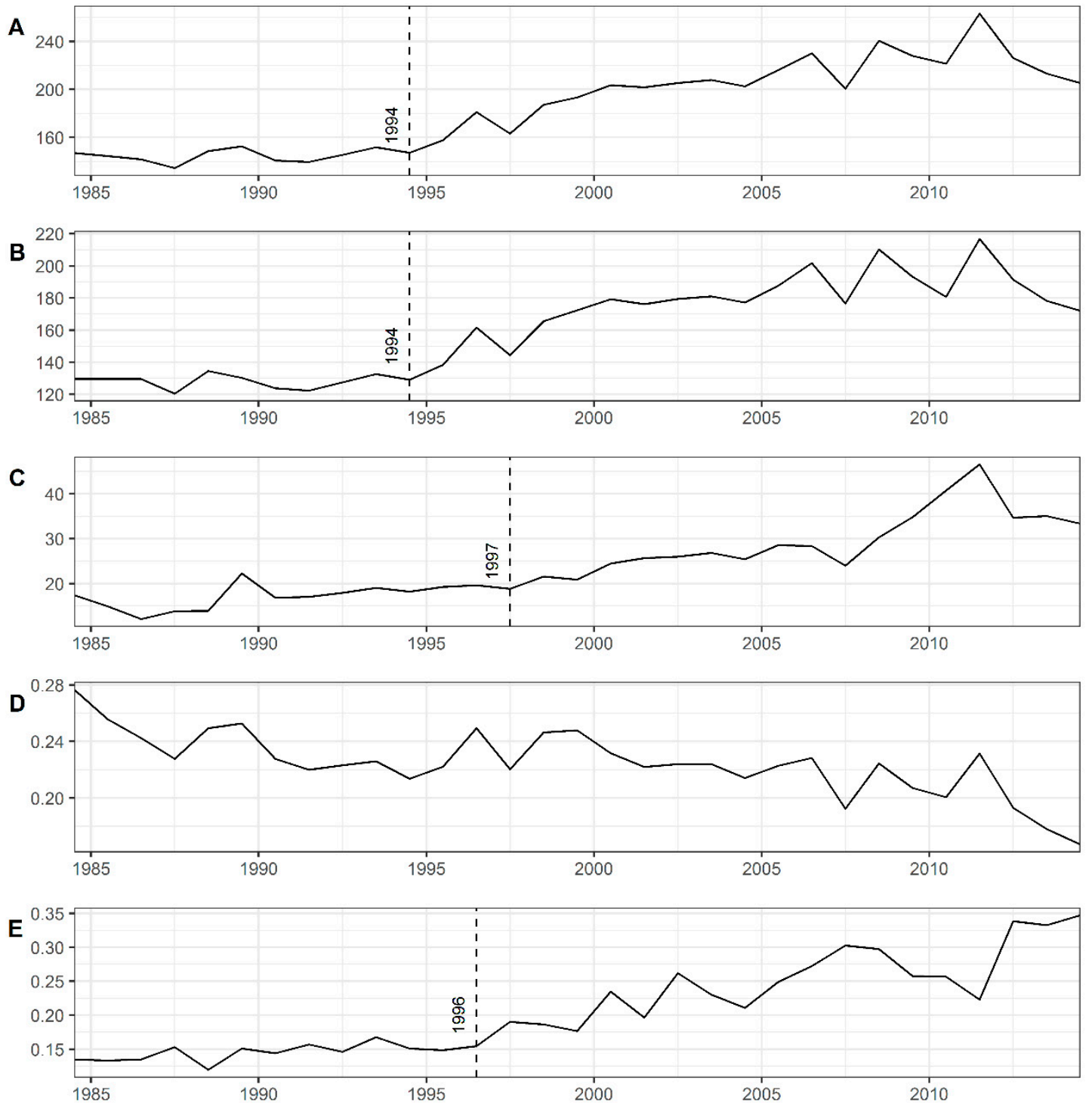

Figure 5. Change points for annual water use by urban counties from 1984 to 2014: (A) total, (B) surface water, (C) groundwater measured in thousands of acre-feet (000s AF); (D) per capita water use (no change point detected) measured in acre-feet (AF); and (E) proportion of total water used. 

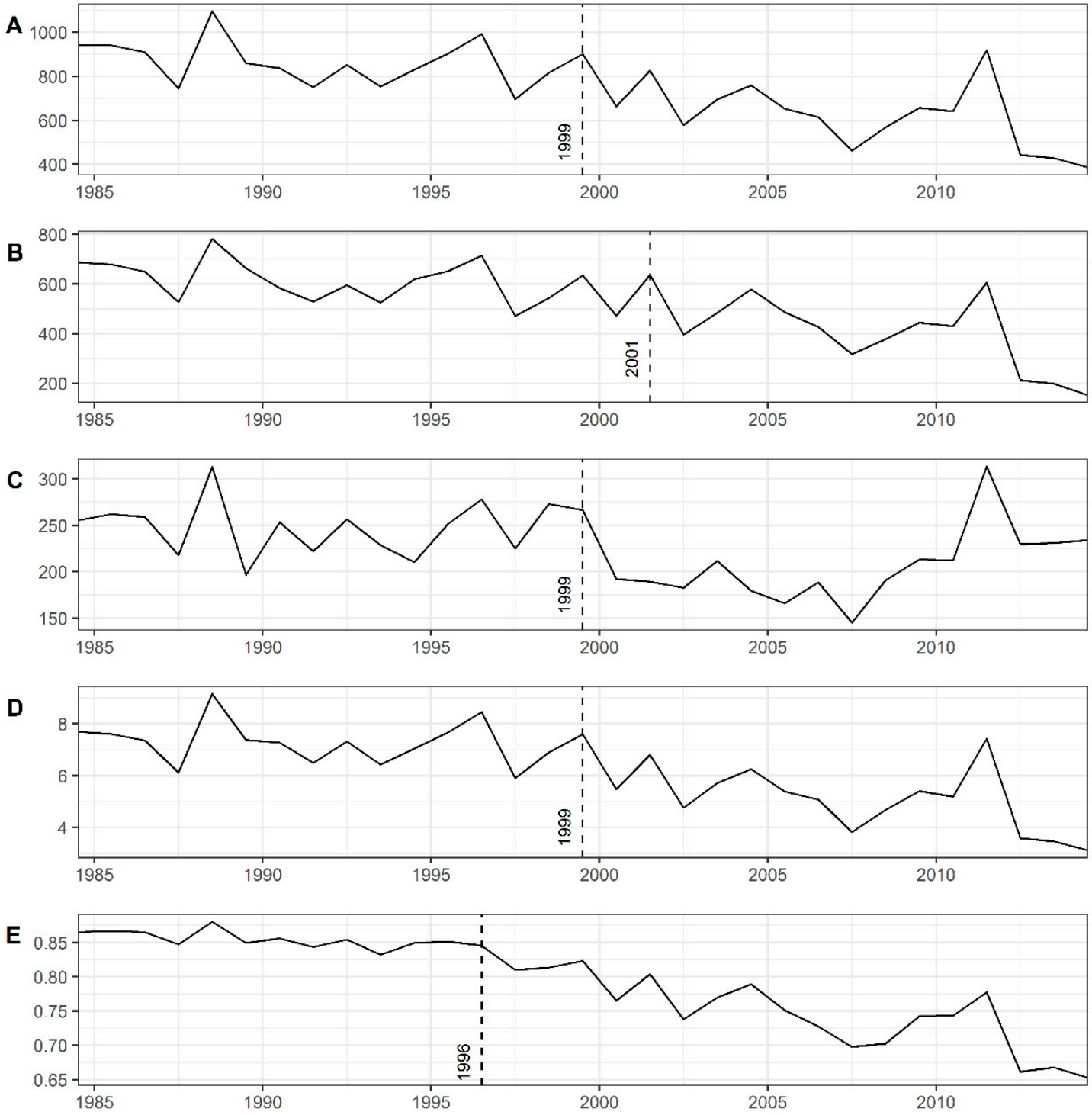

Figure 6. Change points for annual water use by agricultural counties from 1984 to 2014: (A) total, (B) surface water, (C) groundwater measured in thousands of acre-feet (000s AF); (D) per capita water use measured in acre-feet (AF); and (E) proportion of total water used.

Change points occurred in the agricultural variables. Agricultural production in the valley has ebbed and flowed but, in general, has declined since 1970. The critical value of $U$ was exceeded and reached a maximum value in 2002, signaling a downward shift in total crop acres harvested (Figure 7A). Rice acres harvested signaled in 1982 and 1999, revealing three successive periods of decline (Figure 7B). Similarly, the proportion of rice harvested to other field crops harvested signaled in 1974 and 1995, showing three periods of decline (Figure 7D). In 1996, the critical value of $U$ was passed, and the amount of rice produced declined after a stable period (Figure 7C). 

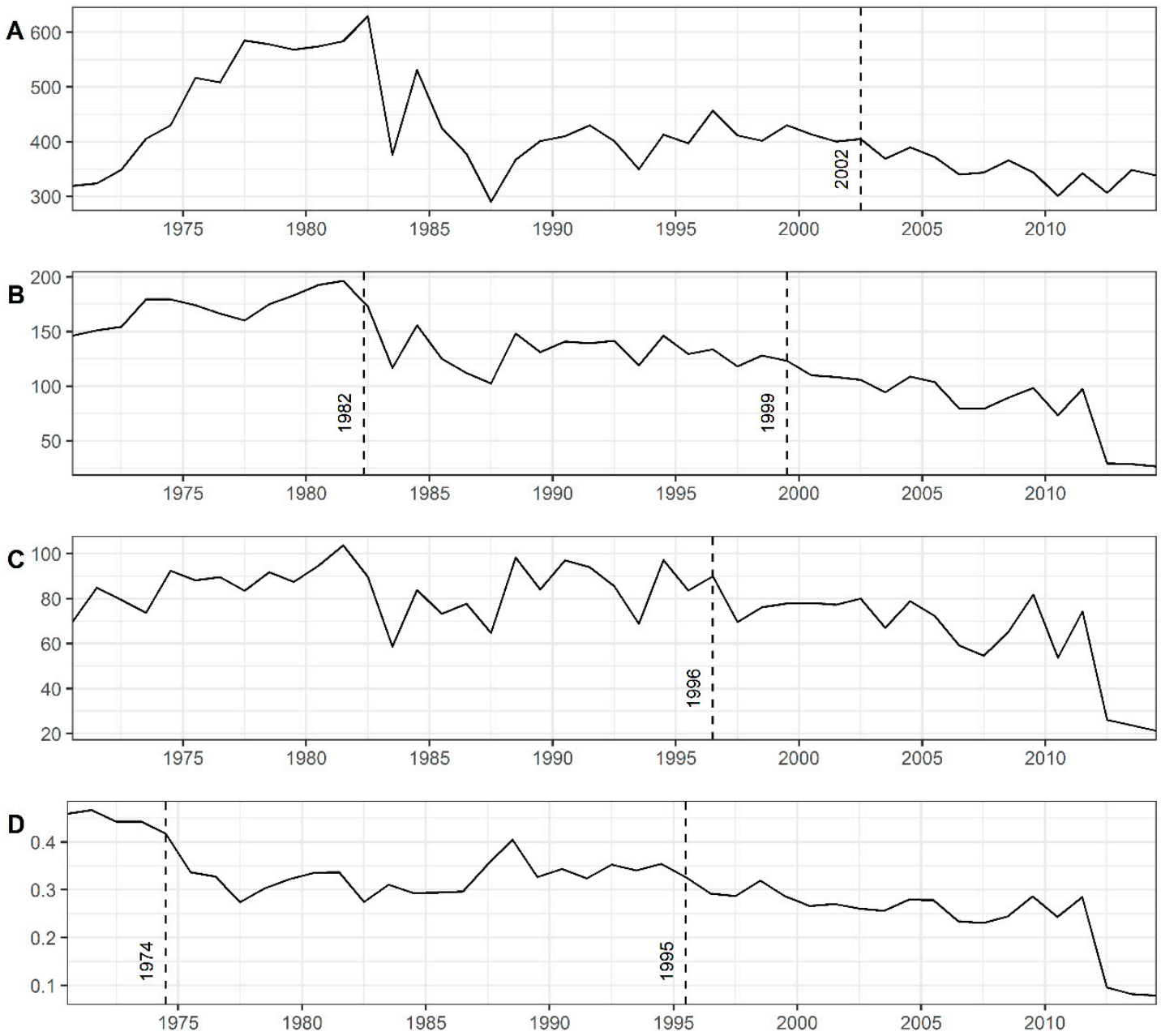

Figure 7. Change points for annual agricultural characteristics by agricultural counties from 1984 to 2014: (A) total annual field crop acres harvested, (B) rice acres harvested measured in thousands of acres harvested (000s acres), (C) rice production measured in thousands of hundredweights (000s cwt), and (D) rice proportion of total field crop acres harvested.

\section{Discussion}

Decision makers receive feedback on changing social and environmental conditions and make managerial interventions based on that feedback [27]. The goal of this research was to assess whether the CPM framework could be used as a method for detecting when "policy windows" open-i.e., to identify empirical periods during which policy or management actions are likely to be taken in response to meaningful shifts in social and environmental data indicators.

During the study period, from 1970 to 2015, several local, regional, and state water management proposals, decisions, and transactions shaped the distribution and allocation of water resources in the lower Colorado River basin. Thus, to evaluate whether the change points detected above represent bounds of policy change windows, this section discusses the observed water management decisions/actions against our CPM findings.

First, we situate the results within the context of two well-documented droughts that occurred during the study period. Next, we compare the results to several high-profile managerial interventions that coincide with groupings of significant change points (Table 2) to answer the second research question: how do change points align with documented managerial interventions related to water resource management. These interventions are drawn from: (1) state water legislation and planning; (2) regional water management 
strategies, proposals, and decisions; and (3) water rights purchases and water resource contracts undertaken in the lower Colorado River basin.

Table 2. Groupings of change points used to compare coincidental documented managerial interventions in water resource management.

\begin{tabular}{|c|c|c|c|}
\hline Period of Change & Time Series Variable & Change Point (Year) & Documented Managerial Event (Year) \\
\hline \multirow[t]{8}{*}{ Period 1 (1994 to 1997) } & Urban counties' water use & 1994 & Senate Bill 1 (1997) \\
\hline & Urban counties' surface water use & 1994 & House Bill 1437 (1999) \\
\hline & Rice share of harvest & 1995 & Water Rights Purchases $(1998,1999)$ \\
\hline & Urban counties' water share & 1996 & Austin-LCRA Water Deal (1999) \\
\hline & Rice produced & 1996 & \\
\hline & $\begin{array}{l}\text { Annual mean maximum } \\
\text { temperature }\end{array}$ & 1997 & \\
\hline & $\begin{array}{l}\text { Summer mean maximum } \\
\text { temperature }\end{array}$ & 1997 & \\
\hline & Urban counties' groundwater use & 1997 & \\
\hline \multirow[t]{6}{*}{ Period 2 (1999 to 2002) } & Agricultural counties' water use & 1999 & Senate Bill 2 (2001) \\
\hline & Agricultural groundwater use & 1999 & Water Rights Purchase (2001) \\
\hline & Agricultural water use per capita & 1999 & \\
\hline & Rice harvested & 1999 & \\
\hline & $\begin{array}{c}\text { Agricultural counties' surface water } \\
\text { use }\end{array}$ & 2001 & \\
\hline & Total field crops harvested & 2002 & \\
\hline \multirow[t]{5}{*}{ Period 3 (2005 to 2007) } & $\begin{array}{l}\text { Lake Buchanan (annual mean sea } \\
\text { level) }\end{array}$ & 2005 & Senate Bill 3 (2007) \\
\hline & $\begin{array}{l}\text { Lake Buchanan (summer mean sea } \\
\text { level) }\end{array}$ & 2005 & Proposition 3 (2013) \\
\hline & Lake Travis (annual mean sea level) & 2005 & Austin-LCRA Water Deal (2007) \\
\hline & $\begin{array}{c}\text { Lake Travis (summer mean sea } \\
\text { level) }\end{array}$ & 2007 & Water Curtailment (2011-2015) \\
\hline & Mean summer river discharge & 2007 & Water Management Plan (2015) \\
\hline
\end{tabular}

\subsection{Droughts}

Texas experiences both acute and chronic droughts. The drought of record occurred in the 1950s, with subsequent droughts occurring at decadal intervals (Figure 2). Three drought events had an impact on the study area during the period under examination. The first occurred from 1995 to 1996, the second between 2005 and 2006, and the third from 2010 to 2015. These events align well with our CPM results. Specifically, the 1995 to 1996 drought resulted in significant agricultural losses across the state, and previous reports have documented losses among the agricultural counties in the lower reaches of the Colorado River basin $[52,66]$. Change points also reflect the impact of the drought on agricultural production. Change points for the variables "rice share of harvest" and "rice produced" in agricultural counties signaled in 1995 and 1996, respectively. Similarly, the drought beginning in 2005 and the more prolonged drought (and one of Texas's worst) beginning in 2010 [34] are reflected in change points for lake characteristics (2005 and 2007) and river discharge (2007). Both droughts depleted the Highland Lakes and inhibited stream flow. While the 2007 indicators signal earlier than the 2010 drought's official beginning, sensitivity in the model is expected and is in line with similar studies [60]. Additionally, the change points identified via the CPM framework are most likely conservative, given our confidence level, and may correspond to the 2005 to 2006 drought. Taken together, the change points occur near previously documented drought events and serve to confirm the use of the CPM framework to detect shifts among the continuous time series variables under analysis. Next, we turn to a discussion of coincidental managerial interventions that occurred within the study period. 


\subsection{Managerial Interventions}

The first grouping of change points is punctuated by growing urban water use along with increasing temperatures in the central Texas region. During this time, the state, along with regional and local water interests, made several decisions and transactions that affected the management of the water held in the Colorado River basin. First, in 1997, the state shifted how it conducted and compiled its water management plan via the passage of Senate Bill 1 (SB 1). The re-tooled statewide water planning effort committed to prioritizing water conservation efforts to bolster the state's water supplies [67]. Additionally, SB 1 established 16 water planning groups throughout the state to create a consensus-driven approach to water management across the state by including local stakeholders in the decision-making and planning processes [35]. Each water management group consists of 20 members. The members represent the full range of water interests and develop a 50-year regional water plan every five years [68]. The Texas Water Development Board (TWDB) synthesizes the groups' plans into the state water plan. Second, the Texas legislature passed House Bill 1437 in 1999 that allowed the LCRA to provide water to Williamson County through an interbasin transfer. The LCRA also purchased water rights from the Garwood Irrigation District, located in the lower reaches of the basin, in 1998. The Garwood rights cost the LCRA approximately USD \$75 million [69] and consisted of 133,000 AFY $\left(1.64 \times 10^{8} \mathrm{~m}^{3}\right.$ year $\left.^{-1}\right)$. After this purchase, the LCRA and the City of Austin entered into a long-term water supply agreement in 1999. The city agreed to pay the LCRA USD \$100 million to extend water delivery from lakes Buchanan and Travis to 2050. The agreement raised the amount of firm water available to 325,000 AFY $\left(4.01 \times 10^{8} \mathrm{~m}^{3} \mathrm{year}^{-1}\right)$. The agreement said that the first 150,000 AF $\left(1.85 \times 10^{8} \mathrm{~m}^{3}\right)$ was free and set a water rate of USD \$105 per AF for the use of water over 150,000 AF to 201,000 AF $\left(1.85 \times 10^{8} \mathrm{~m}^{3}\right.$ to $\left.2.48 \times 10^{8} \mathrm{~m}^{3}\right)$. The agreement, however, specified that payment would not commence until Austin's annual average water use for two consecutive years exceeded 201,000 AF $\left(2.48 \times 10^{8} \mathrm{~m}^{3}\right)$ [70]. The deal reserved a large amount of water for Austin and its future demands, even in drought periods. Additionally, the City of Corpus Christi acquired the rights to 35,000 AFY $\left(4.31 \times 10^{7} \mathrm{~m}^{3}\right.$ year $\left.^{-1}\right)$ of Colorado River water through a purchase and interbasin transfer. Finally, as previously mentioned, the 1995 to 1996 drought affected agricultural productivity in the counties in the lower reaches of the basin.

The policy changes and managerial interventions described above coincide with, or occur shortly after, the first grouping of change points and indicate that significant changes to the water-related variables under analysis were occurring across social and environmental landscapes. In particular, the change points signaled shifts in urban water use and changes in temperature. Significant changes in urban water use signaled in 1994 and 1996, and temperatures in 1997. The direct basin-related managerial events and transactions occurred on the heels of these changes, and the change points correspond to these urban-centric interventions. This suggests that decision makers were responding to changes in urban water use. The role increasing temperatures played in water-related decision-making processes is less clear. Temperatures and precipitation have been shown to affect water use. In particular, residential water use increases under drought conditions [71,72]. Urban water use may be signaling due to significant changes in temperature; yet, population growth in the urban counties most likely contributed to the increase as well. Finally, the change points related to agricultural losses (i.e., decline in annual rice harvested in 1996) suggest that the 1996 drought affected these counties with ramifications for agricultural water use punctuated in the second period of change points.

The decline in water use by agricultural counties defines the second grouping of change points (1999 to 2002). The amount of rice and total crops harvested also declined significantly. During this period, a few major water-related policies and transactions were undertaken. In 2001, the Texas Legislature passed Senate Bill 2. This piece of legislation created groundwater management areas (GMAs) [73]. The creation of GMAs was an important moment for water planning and conservation across the state. Its impact on surface water use across the study area, however, is negligible (i.e., a change point was not 
observed in groundwater use), and the significant decline of agricultural water use during period 2 did not influence the passage of SB 2. In 2001, the LCRA purchased the rights to $55,000 \mathrm{AF}\left(6.78 \times 10^{7} \mathrm{~m}^{3}\right)$ in the lower portion of the basin. This purchase included the last group of privately held senior water rights in the watershed and allowed the LCRA to control the major irrigation districts in the Texas Rice Belt. Agricultural operations, including rice farmers, began to contract with the LCRA to purchase interruptible water. It is best to view the second group of change points as feedback from managerial interventions and environmental processes that took place during the first period discussed above. In this view, significant declines in agricultural water use and crops are a function of earlier managerial interventions, which were responses to changes in earlier social and environmental conditions. This interpretation suggests that the CPM framework returns change points not only before managerial interventions but also after them. In this way, the CPM framework could be used to monitor the effectiveness of prior interventions across appropriate sets of time series data.

The final grouping of change points corresponds to declines in lake levels (2005 and 2007). The low lake levels were the result of the 2005 and 2010 droughts and severely impacted water use in the basin. During this period, the state enacted and passed two water-related policies, and the droughts triggered multiple managerial responses to extend supplies during a time of extreme water scarcity. In 2007, the Texas Legislature passed a major piece of water legislation. Senate Bill 3 called for the protection of environmental flows in the state's rivers and estuaries [35] and required groundwater districts to produce groundwater management plans [67]. Additionally, in 2013, Texans voted in favor of Proposition 6. Proposition 6 called for the state, using monies from its Economic Stabilization Fund (ESF), to create the State Water Implementation Fund for Texas (SWIFT) and the State Water Implementation Revenue Fund for Texas (SWIRFT). These funds finance priority projects outlined in the state water plan. Within the basin, Austin and the LCRA brokered an extension of their earlier water agreement in 2007. The two entities formed a formal water partnership through 2100 [74]. Yet, these managerial events were less of a response to the 2005 and 2010 droughts and more of a response to growing urban population demands. The change points link more appropriately to water availability in the basin.

The drought worsened in 2011, and water levels in lakes Buchanan and Travis began to decline. In 2012, the LCRA asked the Texas Commission on Environmental Quality (TCEQ) to grant an emergency order that would change its water management plan. Specifically, the order called for the cutoff of the interruptible water supply contracts held mostly by agricultural interests. By 2013, water levels in lakes Buchanan and Travis measured 43 percent of their combined storage capacity [75], and the LCRA was forced to file additional emergency orders in 2013, 2014, and 2015. Each year, the TCEQ approved the orders. In 2015, the LCRA updated its water management plan to provide more flexibility to its curtailment and cut-off procedures. The new water management plan made significant changes to the way in which the LCRA manages interruptible water contracts [76].

The managerial interventions implemented beginning in 2012 and the redrawn 2015 water management plan were a response to severe drought conditions that occurred in central Texas from 2010 to 2015, which followed directly after the less severe 2005 drought. The CPM signals changes in water levels (2005 and 2007) before the worst years of the drought. These signals indicate that water availability in the basin, beginning with the 2005 drought, never fully recovered. This suggests that the CPM framework is sensitive to extreme fluctuations. Authorities, however, delayed managerial interventions until lake levels threatened urban water security.

\section{Conclusions}

The purpose of this research was to examine the extent to which significant changes in social and environmental conditions in a highly urbanized watershed with historic and competing agricultural water demands coincided with water-related managerial interventions. More precisely, we used the CPM framework to identify time periods when feedback 
from social and environmental data indicators (i.e., change points) might serve as a signal to decision makers that actions should be taken [27]. We grouped change points with similar timeframes and found that these change points corresponded to "policy windows" during which documented water-related managerial events took place. Stated another way, key managerial decisions occurred during or just after significant periods of change. We also found that the change points, in some cases, aligned more appropriately to future managerial events. Because of this, our findings suggest that the CPM framework is useful for shedding light on the nature of public decision making related to (water) resource management. Namely, public decision makers appear to react to feedback that they receive as observable changes in social and physical data indicators.

One implication is that monitoring indicators more prospectively-thus anticipating when they are likely to undergo meaningful change-should be useful for resource planning and policy designed to avoid negative outcomes (as opposed to experiencing and then reacting to such outcomes). Indeed, an important goal of environmental managers is to identify problems in socio-ecological systems and take actions that build the capacity of those systems to adapt and thrive in changing conditions. Our study suggests that the CPM framework might have a useful role to play in this planning process going forward; however, it cannot nor should it be the only tool in the analytical toolbox. For one, much publicly available time series data (including the indicators tested here) are annual measures. Data series with higher temporal resolution should be used to observe how the CPM framework responds to changes in data resolution. This would help gauge the appropriate resolution with which to identify key change points across variables of interest and discern when to act on changes. In addition, applications of the CPM framework depend on observed data. Thus, future work might experiment with coupling CPM and trend analyses in attempts to detect anticipated change points. Finally, qualitative techniques, such as interviews with key water stakeholders, are needed to further examine how managerial events and corresponding change points impact managerial interventions. Still, despite these drawbacks, our results demonstrate that applying the CPM framework to social and environmental indicators can help explain why (water) resource management actions are taken when they are taken.

Author Contributions: Conceptualization, B.L.L., R.C.W. and R.R.H.III; methodology, B.L.L. and R.C.W.; validation, B.L.L. and R.C.W.; formal analysis, B.L.L.; investigation, B.L.L.; data curation, B.L.L.; writing—original draft preparation, B.L.L.; writing-review and editing, B.L.L., R.C.W. and R.R.H.III; visualization, B.L.L. All authors have read and agreed to the published version of the manuscript.

Funding: This research received no external funding.

Conflicts of Interest: The authors declare no conflict of interest.

\section{References}

1. Molle, F.; Wester, P.; Hirsch, P. River basin development and management. In Water for Food—Water for Life: A Comprehensive Assessment of Water Managemen in Agrculture; Molden, D., Ed.; Earthscan: London, UK, 2007.

2. Hellegers, P.; Leflaive, X. Water allocation reform: What makes it so difficult? Water Int. 2015, 40, 273-285. [CrossRef]

3. OECD. Water Resources Allocation: Sharing Risks and Opportunities; OECD Publishing: Paris, France, 2015.

4. Molle, F.; Berkoff, J. Cities vs. agriculture: A review of intersectoral water re-allocation. Nat. Resour. Forum 2009, $33,6-18$. [CrossRef]

5. Howe, C.W. Water markets in Colorado: Past performance and needed changes. In Markets for Water: Potential and Performance; Easter, K.W., Rosegrant, M.W., Dinar, A., Eds.; Kluwer Academic Publishers: Boston, MA, USA, 1998.

6. Celio, M.; Giordano, M. Agriculture-urban water transfers: A case study of Hyderabad, South-India. Paddy Water Environ. 2007, 5, 229-237. [CrossRef]

7. Celio, M.; Scott, C.A.; Giordano, M. Urban-agricultural water appropriation: The Hyderabad, India case. Geogr. J. 2010, 176, 39-57. [CrossRef]

8. Birkenholtz, T. Dispossessing irrigators: Water grabbing, supply-side growth and farmer resistance in India. Geoforum 2016, 69, 94-105. [CrossRef]

9. Gleick, P.H. Transitions to freshwater sustainability. Proc. Natl. Acad. Sci. USA 2018, 115, 8863-8871. [CrossRef] 
10. Oki, T.; Kanae, S. Global hydrological cycles and world water resources. Science 2006, 313, 1068-1072. [CrossRef]

11. Vörösmarty, C.J.; Green, P.; Salisbury, J.; Lammers, R.B. Global water resources: Vulnerability from climate change and population growth. Science 2000, 289, 284-288. [CrossRef]

12. Mekonnen, M.M.; Hoekstra, A.Y. Four billion people facing severe water scarcity. Sci. Adv. 2016, 2, e1500323. [CrossRef]

13. Dziegielewski, B.; Kiefer, J.C. U.S. Water Demand, Supply and Allocation: Trends and Outlook; 2007-R-3; Institute for Water Resources: Alexandria, VA, USA, 2007.

14. Swyngedouw, E. Power, nature, and the city. The conquest of water and the political ecology of urbanization in Guayaquil, Ecuador: 1880-1990. Environ. Plan. A 1997, 29, 311-332. [CrossRef]

15. Swyngedouw, E. Social Power and the Urbanization of Water: Flows of Power; Oxford University Press: New York, NY, USA, 2004.

16. Bakker, K. Archipelagos and networks: Urbanization and water privatization in the South. Geogr. J. 2003, 169, 328-341. [CrossRef]

17. Scott, C.A.; Pablos, N.P. Innovating resource regimes: Water, wastewater, and the institutional dynamics of urban hydraulic reach in northwest Mexico. Geoforum 2011, 42, 439-450. [CrossRef]

18. Kaika, M. City of Flows: Modernity, Nature, and the City; Routledge: New York, NY, USA, 2005.

19. Bell, M.G. Historical Political Ecology of Water: Access to Municipal Drinking Water in Colonial Lima, Peru (1578-1700). Prof. Geogr. 2015, 67, 504-526. [CrossRef]

20. Wagner, K. Status and Trends of Irrigated Agriculture in Texas; TWRI EM-115; Texas Water Resources Institute: College Station, TX, USA, 2012

21. Shupe, S.J.; Weatherford, G.D.; Checchio, E. Western water rights: The era of reallocation. Nat. Resour. J. 1989, $29,413$.

22. Villarejo, D. 93640 at Risk: Farmers, Workers, and Townspeople in An Era of Water Uncertainty; The California Institute for Rural Studies: Davis, CA, USA, 1996.

23. Molle, F.; Hoogesteger, J.; Mamanpoush, A. Macro-and micro-level impacts of droughts: The case of the Zayandeh Rud river basin, Iran. Irrigigation Drain. 2008, 57, 219. [CrossRef]

24. Chang, C.; Griffin, R.C. Water marketing as a reallocative institution in Texas. Water Resour. Res. 1992, 28, 879-890. [CrossRef]

25. Debaere, P.; Li, T. The effects of water markets: Evidence from the Rio Grande. Adv. Water Resour. 2020, 145, 103700. [CrossRef]

26. Molle, F. Development Trajectories of River Basins: A Conceptual Framework; International Water Management Institute: Colombo, Sri Lanka, 2003.

27. Platt, R.H. Land Use and Society: Geography, Law, and Public Policy, 3rd ed.; Island Press: Washington, DC, USA, 2014.

28. Lykou, R.; Tsaklidis, G.; Papadimitriou, E. Change point analysis on the Corinth Gulf (Greece) seismicity. Phys. A Stat. Mech. Appl. 2020, 541, 123630. [CrossRef]

29. Barboza, L.A.; Vásquez, P.; Mery, G.; Sanchez, F.; García, Y.E.; Calvo, J.G.; Rivas, T.; Pérez, M.D.; Salas, D. The Role of Mobility and Sanitary Measures on the Delay of Community Transmission of COVID-19 in Costa Rica. Epidemiologia 2021, 2, 22. [CrossRef]

30. Hallema, D.W.; Sun, G.; Caldwell, P.V.; Norman, S.P.; Cohen, E.C.; Liu, Y.; Bladon, K.D.; McNulty, S.G. Burned forests impact water supplies. Nat. Commun. 2018, 9, 1307. [CrossRef]

31. Adams, J.A. Damming the Colorado: The Rise of the Lower Colorado River Authority 1933-1939; Texas A\&M University Press: College Station, TX, USA, 1990.

32. Woodruff, C.M. Land Resource Overview of the Capital Area Planning Council Region, Texas-A Nontechnical Guide; Bureau of Economic Geology: Austin, TX, USA, 1979.

33. Barlow, M.; Nigam, S.; Berbery, E.H. ENSO, Pacific decadal variability, and US summertime precipitation, drought, and stream flow. J. Clim. 2001, 14, 2105-2128. [CrossRef]

34. Combs, S. The Impact of the 2011 Drought and Beyond; Texas Comptroller: Austin, TX, USA, 2012.

35. Sansom, A. Water in Texas: An Introduction; University of Texas Press: Austin, TX, USA, 2008.

36. Coff, R.; Darling, K. Travis County Trend Profile: Selected Census Data from 1990, 2000, and 2010; Travis County Health and Human Services \& Veterans Service, Research \& Planning Division: Travis County, TX, USA, 2012; pp. 1-4.

37. Baldwin, K.; Dohlman, E.; Childs, N.; Foreman, L. Consolidation and Structural Change in the US Rice Sector; RCS-11d-01; Economic Research Service/USDA: Washington, DC, USA, 2011.

38. Banks, J.H.J.; Babcock, J.E. Corralling the Colorado: The First Fifity Years of the Lower Colorado River Authority; Eakin Press: Austin, TX, USA, 1988.

39. Lavy, B.L. Cooperation, fragmentation and control: News media representations of changing water access from Austin to the Texas Rice Belt. Water Altern. 2020, 13, 779-799.

40. LCRA. About LCRA. Available online: http://www.lcra.org/about/Pages/default.aspx (accessed on 5 September 2017).

41. Kelly, M.E. Water for the environment: Updating Texas water law. In Water Policy in Texas: Responding to the Rise of Scarcity; Griffin, R.C., Ed.; RFF Press: Washington, DC, USA, 2011.

42. TWDB. Water for Texas: State Water Plan; Texas Water Development Board: Austin, TX, USA, 2017.

43. Franczyk, J.; Chang, H. Spatial Analysis of Water Use in Oregon, USA, 1985-2005. Water Resour. Manag. 2009, $23,755-774$. [CrossRef]

44. Kaika, M. Constructing scarcity and sensationalising water politics: 170 days that shook Athens. Antipode 2003, 35, 919-954. [CrossRef]

45. Bakker, K. Privatizing Water, Producing Scarcity: The Yorkshire Drought of 1995. Econ. Geogr. 2000, 76, 4-27. [CrossRef] 
46. Linton, J.; Budds, J. The hydrosocial cycle: Defining and mobilizing a relational-dialectical approach to water. Geoforum 2014, 57, 170-180. [CrossRef]

47. Cech, T.V. Principles of Water Resources: History, Development, and Management, 3rd ed.; John Wiley \& Sons, Inc.: Hoboken, NJ, USA, 2010.

48. McKee, T.B.; Doesken, N.J.; Kleist, J. The relationship of drought frequency and duration to time scales. In Proceedings of the 8th Conference on Applied Climatology, Anaheim, CA, USA, 17-22 January 1993; pp. 179-183.

49. McKee, T.B.; Doesken, N.J.; Kleist, J. Drought monitoring with multiple time scales. In Proceedings of the 9th Conference on Applied Climatology, Dallas, TX, USA, 15-20 January 1995; pp. 233-236.

50. Agnew, C. Using the SPI to identify drought. Drought Netw. News 2000, 12, 6-12.

51. WMO. Standardized Precipitation Index User Guide; World Meteorological Organization: Geneva, Switzerland, 2012.

52. Hayes, M.J.; Svoboda, M.D.; Wilhite, D.A.; Vanyarkho, O.V. Monitoring the 1996 drought using the standardized precipitation index. Bull. Am. Meteorol. Soc. 1999, 80, 429-438. [CrossRef]

53. The Nature Conservancy. Indicators of Hydrologic Alteration (IHA), version 7.1; The Nature Conservancy: Arlington County, VA, USA, 2009

54. The Nature Conservancy. Indicators of Hydrologic Alteration Version 7.1 User's Manual; The Nature Conservancy: Arlington County, VA, USA, 2009.

55. Richter, B.D.; Baumgartner, J.V.; Powell, J.; Braun, D.P. A method for assessing hydrologic alteration within ecosystems. Conserv. Biol. 1996, 10, 1163-1174. [CrossRef]

56. Mathews, R.; Richter, B.D. Application of the indicators of hydrologic alteration software in environmental flow setting. JAWRA J Am. Water Resour. Assoc. 2007, 43, 1400-1413. [CrossRef]

57. OECD. OECD Environmental Outlook to 2050; OECD Publishing: Paris, France, 2012.

58. Ross, G.J. Parametric and Nonparametric Sequential Change Detection in R: The CPM Package. J. Stat. Softw. 2015, 66, 1-20. [CrossRef]

59. Team, R.C. R: A Language and Environment for Statistical Computing, version 3.3.2; R Foundation for Statistical Computing: Vienna, Austria, 2016

60. Beaulieu, C.; Chen, J.; Sarmiento, J.L. Change-point analysis as a tool to detect abrupt climate variations. Philos. Trans. R. Soc. A Math. Phys. Eng. Sci. 2012, 370, 1228-1249. [CrossRef] [PubMed]

61. Thomson, J.R.; Kimmerer, W.J.; Brown, L.R.; Newman, K.B.; Nally, R.M.; Bennett, W.A.; Feyrer, F.; Fleishman, E. Bayesian change point analysis of abundance trends for pelagic fishes in the upper San Francisco Estuary. Ecol. Appl. 2010, 20, 1431-1448. [CrossRef]

62. Obisesan, K.; Lawal, M.; Bamiduro, T.; Adelakun, A. Data Visualization and Change-point detection in Environmental Data: The Case of Water Pollution in Oyo State Nigeria. J. Sci. Res. 2013, 12, 179-188.

63. Hawkins, D.M.; Qiu, P.; Kang, C.W. The Changepoint Model for Statistical Process Control. J. Qual. Technol. 2003, 35, 355-366. [CrossRef]

64. Hawkins, D.M.; Zamba, K.D. Statistical Process Control for Shifts in Mean or Variance Using a Changepoint Formulation. J. Qual. Technol. 2005, 37, 21-31. [CrossRef]

65. Ross, G.J.; Adams, N.M. Two nonparametric control charts for detecting arbitrary distribution changes. J. Qual. Technol. 2012, 44, 102. [CrossRef]

66. WGA. 1996: Drought Response Action Plan; Western Governors' Association: Denver, CO, USA, 1996; p. 12.

67. Rogers, E.W.; Clancy, L. State water planning: Its history and its challenges. In Proceedings of the 2014 Texas City Attorneys Association Summer Conference, South Padre Island, TX, USA, 18-20 June 2014.

68. TWDB. Regional Water Planning in Texas; Texas Water Development Board: Austin, TX, USA, 2016.

69. Kaiser, R. Texas water law and organizations. In Water Policy in Texas: Responding to the Rise of Scarcity; Griffin, R.C., Ed.; RFF Press: Washington, DC, USA, 2011.

70. LCRA and the City of Austin. First Amendment to December 10, 1987 Comprehensive Water Settlement Agreement between City of Austin and Lower Colorado River Authority; Lower Colorado River Authority: Austin, TX, USA, 1999.

71. Kenney, D.S.; Klein, R.A.; Clark, M.P. Use and Effectiveness of Municipal Water Restrictions during Drought in Colorado 1. JAWRA J. Am. Water Resour. Assoc. 2004, 40, 77-87. [CrossRef]

72. Mini, C.; Hogue, T.; Pincetl, S. The effectiveness of water conservation measures on summer residential water use in Los Angeles, California. Resour. Conserv. Recycl. 2015, 94, 136-145. [CrossRef]

73. Texas Water Code 35.001. 2001. Available online: https://statutes.capitol.texas.gov/docs/wa/htm/wa.35.htm (accessed on 5 September 2017).

74. LCRA and the City of Austin. Supplemental Water Supply Agreement by and between the City of Austin and the Lower Colorado River Authority; Lower Colorado River Authority: Austin, TX, USA, 2007.

75. AARO. Drowning in the Central Texas Drought; Austin Area Research Organization: Austin, TX, USA, $2015 ;$ p. 11.

76. LCRA. Lakes Buchanan and Travis Water Management Plan. and Drought Contingency Plans; Lower Colorado River Authority: Austin, TX, USA, 2015. 